\title{
Regenerating the liver: not so simple after all? [version 1; peer
}

\section{review: 3 approved]}

\author{
Malcolm R. Alison1, Wey-Ran Lin²,3 \\ ${ }^{1}$ Centre for Tumour Biology, Barts and The London School of Medicine and Dentistry, London, UK \\ 2Department of Gastroenterology and Hepatology, Linkou Chang Gung Memorial Hospital, Taoyuan 333, Taiwan \\ ${ }^{3}$ Department of Medicine, Chang Gung University, Taoyuan 333, Taiwan
}

V1 First published: 26 Jul 2016, 5(F1000 Faculty Rev):1818
https://doi.org/10.12688/f1000research.8827.1

Latest published: 26 Jul 2016, 5(F1000 Faculty Rev):1818

https://doi.org/10.12688/f1000research.8827.1

\begin{abstract}
Under normal homeostatic conditions, hepatocyte renewal is a slow process and complete turnover likely takes at least a year. Studies of hepatocyte regeneration after a two-thirds partial hepatectomy (2/3 $\mathrm{PH}$ ) have strongly suggested that periportal hepatocytes are the driving force behind regenerative re-population, but recent murine studies have brought greater complexity to the issue. Although periportal hepatocytes are still considered pre-eminent in the response to $2 / 3 \mathrm{PH}$, new studies suggest that normal homeostatic renewal is driven by pericentral hepatocytes under the control of Wnts, while pericentral injury provokes the clonal expansion of a subpopulation of periportal hepatocytes expressing low levels of biliary duct genes such as Sox9 and osteopontin. Furthermore, some clarity has been given to the debate on the ability of biliary-derived hepatic progenitor cells to generate physiologically meaningful numbers of hepatocytes in injury models, demonstrating that under appropriate circumstances these cells can re-populate the whole liver.
\end{abstract}

\section{Keywords}

hepatocyte renewal, hepatocyte regeneration, pericentral hepatocytes, periportal hepatocytes, liver regeneration

\section{Open Peer Review

\begin{tabular}{|c|c|c|c|}
\hline \multicolumn{4}{|c|}{ Approval Status $\checkmark$} \\
\hline & 1 & 2 & 3 \\
\hline $\begin{array}{l}\text { version } 1 \\
26 \text { Jul } 2016\end{array}$ & $\checkmark$ & $\checkmark$ & $\checkmark$ \\
\hline
\end{tabular} \\ Faculty Reviews are review articles written by the prestigious Members of Faculty Opinions. The articles are commissioned and peer reviewed before publication to ensure that the final, published version is comprehensive and accessible. The reviewers who approved the final version are listed with their names and affiliations.}

\section{George Michalopoulos, University of} Pittsburgh School of Medicine, Pittsburgh, USA

2. Lola Reid, University of North Carolina School of Medicine, Chapel Hill, USA

3. Anna Mae Diehl, Duke University Medical Center, Durham, USA

Any comments on the article can be found at the end of the article. 
Corresponding author: Malcolm R. Alison (m.alison@qmul.ac.uk)

Competing interests: The authors declare that they have no competing interests.

Grant information: The author(s) declared that no grants were involved in supporting this work.

Copyright: (c) 2016 Alison MR and Lin WR. This is an open access article distributed under the terms of the Creative Commons Attribution License, which permits unrestricted use, distribution, and reproduction in any medium, provided the original work is properly cited.

How to cite this article: Alison MR and Lin WR. Regenerating the liver: not so simple after all? [version 1; peer review: 3 approved] F1000Research 2016, 5(F1000 Faculty Rev):1818 https://doi.org/10.12688/f1000research.8827.1

First published: 26 Jul 2016, 5(F1000 Faculty Rev):1818 https://doi.org/10.12688/f1000research.8827.1 


\section{Introduction}

Liver disease is an increasing problem worldwide, and with the seemingly intractable problem of an insufficient number of livers available for transplantation, attention is turning to alternate sources of supply. In particular, the ability to ex vivo-expand the number of good-quality hepatocytes from the limited number of available livers is viewed as an attractive proposition. Thus, much effort is being spent in defining liver populations in terms of their 'stemness' or clonogenic potential, cell surface characteristics (for isolation), and their location within the liver. Although our understanding of the organization and renewal of the likes of the hematopoietic system and the small intestine is well advanced, it might surprise readers of this article to find that hepatologists cannot even agree whether the liver has a hierarchical organization, conforming to a stem cell and lineage system.

Many previous studies into the kinetics of hepatocyte proliferation have concentrated on the periportal zone, since hepatocytes located here are the first to enter DNA synthesis after a two-thirds partial hepatectomy $(2 / 3 \mathrm{PH})$ (reviewed in 1) and undergo more rounds of replication than midzonal and pericentral hepatocytes. In the '80s, pulse-chase analysis of rats injected with tritiated thymidine suggested a slow migration of hepatocytes along the portal vein (PV)-to-central vein (CV) axis, formally proposed as the "streaming liver' hypothesis ${ }^{2}$. Studies in human liver have also supported a periportal origin of hepatocyte generation; distinct maturational stages were found along the same PV-CV axis ${ }^{3}$, and while studying mitochondrial DNA (mtDNA) mutation analysis, we have discovered clonal populations of hepatocytes invariably connected to the portal limiting plate $\mathrm{p}^{4,5}$.

The long-term retention of DNA labels in cells has been advanced as evidence for slowly cycling stem cells, and in the mouse DNA label-retaining cells are in and around the portal tracts, providing further support for a periportal stem cell niche in this location ${ }^{6}$. Employing tamoxifen-inducible genetic lineage tracing from the Sox 9 locus in the mouse liver, Furuyama et al. ${ }^{7}$ followed the fate of labeled biliary cells by X-gal staining, observing marked cells seemingly migrating along the PV-CV axis to eventually replace the whole parenchyma within 8 to 12 months. These observations would imply that cells within the biliary tree are drivers not only of hepatocyte replacement when regeneration from existing hepatocytes is compromised-see section on hepatic progenitor cells (HPCs), entitled 'periportal/portal stem cell niche(s)'-but also of normal hepatocyte turnover. Unfortunately, these findings have not been replicated by others. For example, Tarlow et al. ${ }^{8}$ found that Sox9-positive ductal cells made only a minimal contribution to parenchymal regeneration in a number of liver injury models; moreover, even when high-dose tamoxifen was used to induce Sox9 expression in periportal hepatocytes, these marked hepatocytes did not replace the remainder of the parenchyma. Lineage labeling from Sox9-expressing ductal plate cells also indicated no large-scale parenchymal replacement from these cells, descendants being restricted to a few periportal hepatocytes as well as the intrahepatic biliary tree ${ }^{9}$. Achieving specific marker gene activation in all mouse hepatocytes with an adeno-associated viral vector has also failed to indicate any significant contribution of biliary cells to the hepatic parenchyma, not only under normal homeostatic conditions but also after $2 / 3 \mathrm{PH}$ or carbon tetrachloride $\left(\mathrm{CCl}_{4}\right)$ toxic injury ${ }^{10}$. Retroviral-mediated $\beta$-galactosidase gene transfer to rat livers 24 hours after a $2 / 3 \mathrm{PH}$ has also seemingly put a 'nail in the coffin' of the 'streaming liver' hypothesis ${ }^{11,12}$, given that there was no apparent movement of these marked hepatocytes over the next year or more. A recent review summarizes ${ }^{13}$ these two studies with the statement "it is important to consider that much literature refutes the notion of either portal-to-central or central-to-portal hepatocyte streaming during homeostasis". This review now describes several studies that re-invigorate the streaming debate as well as provide convincing evidence that biliary-derived HPCs can be an effective reservoir for new parenchymal (hepatocyte) cells.

\section{A pericentral hepatic stem cell niche?}

In the mouse, a single layer of essentially diploid hepatocytes (two-thirds diploid and one-third tetraploid) abuts the hepatic (central) veins, expressing the Wnt target gene products Axin2 (axis inhibition protein 2) and glutamine synthetase (GS) $)^{14}$. Axin2 negatively regulates Wnt signaling, promoting phosphorylation and degradation of $\beta$-catenin ${ }^{15}$. These hepatocytes lack expression of the differentiated gene product carbamoyl-phosphate synthase 1 (CPS-1) but do express the transcription factors HNF4 $\alpha$ (for hepatocyte fate determination) and Tbx3 (a pluripotency factor); Tbx is also expressed in hepatoblasts. Under normal homeostatic conditions, genetic lineage labeling from these Axin2-positive hepatocytes with inducible Cre revealed that these cells migrated concentrically away from the hepatic veins, differentiating into Axin2- and GS-negative but CPS-positive polyploid hepatocytes that within a year had reached the portal rim (Figure 1). No cholangiocyte differentiation was seen from these cells. Hepatic vein endothelial cells expressed high levels of Wnt 2 and Wnt9b,

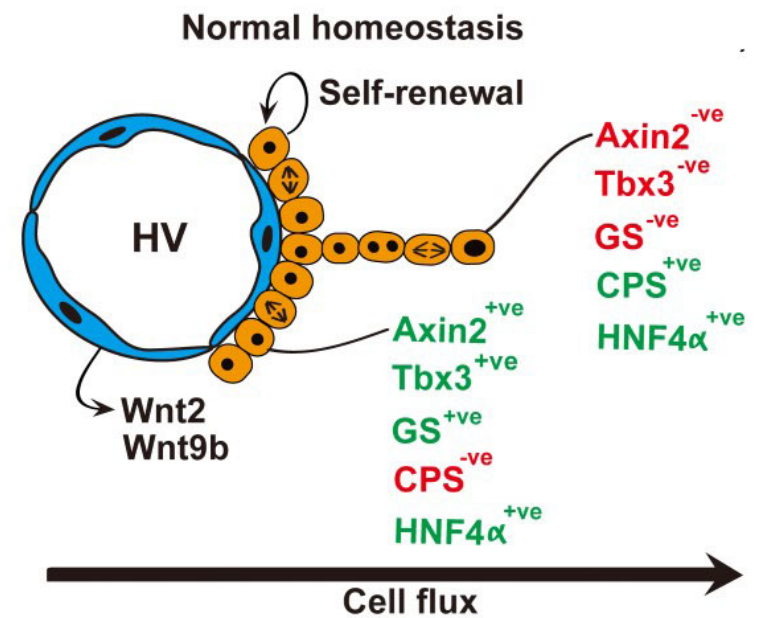

Figure 1. A pericentral stem/progenitor niche. Under normal homeostatic conditions essentially diploid hepatocytes abut the central veins, they may self-renew, and the progeny of these cells migrate concentrically away from the central vein towards the portal regions. This migration is accompanied by polyploidization and changes in metabolic status appropriate to position along the central vein-portal vein axis. See section entitled 'a pericentral hepatic stem cell niche?' and 14 for further details. 
and disruption of this Wnt signaling reduced both Axin2 expression and the rate of cell proliferation of these Axin2-positive hepatocytes. Thus, hepatic vein endothelial cells could constitute the stem cell niche. Tracing dilution of a stable DNA label, the authors estimated that the Axin2-positive hepatocytes divided every 14 days, twice as fast as Axin2-negative hepatocytes. Moreover, the pericentral ring of Axin2-positive hepatocytes was never infiltrated by Axin2-negative hepatocytes, suggesting to the authors that the Axin2-positive population is self-renewing-one functional definition of stem cells. On the other hand, Axin2negative hepatocytes could have penetrated the pericentral hepatocyte ring, becoming Axin2 positive when in contact with the hepatic venous system. Indeed, over 20 years ago, Kuo and Darnell ${ }^{16}$ noted that widening of the GS-positive zone did not occur after a $75 \%$ hepatectomy in mice even though the GS-positive hepatocytes divided, reasoning (correctly, it seems) that the immediate microenvironment of the hepatic venous system provides the signals for GS gene expression.

Wnts regulate stem cell renewal in many tissues, and in mouse liver Wnt signaling is implicated in metabolic zonation ${ }^{17}$ and liver regeneration ${ }^{18}$, seemingly spatially coordinated by the combination of R-spondin (RSPO) ligands, their leucine-rich repeat-containing $\mathrm{G}$ protein-coupled receptors LGR4 and LGR5 and the ZNRF3/ RNF43 receptor-degrading enzymes ${ }^{19,20}$. Planas-Paz et al. ${ }^{19}$ found that RSPO1 improved liver regeneration but that LGR4/5 loss of function resulted in hypoplasia; the authors concluded that the RSPO-LGR4/5-ZNRF3/RNF43 module not only controls metabolic zonation but also acts as a hepatic growth/size rheostat. Surprisingly, the authors failed to confirm the observations of the Nusse group ${ }^{14}$, finding that the LGR5-expressing pericentral hepatocytes did not show an increased proliferative rate compared with hepatocytes in other zones, nor did they find that descendants of these pericentral hepatocytes extensively re-populated the liver during normal homeostasis or following a 2/3 PH! Clearly, further studies are required to clarify the role of pericentral hepatocytes.

Apart from the role of Wnt signaling, many other growth factors, cytokines, and their signaling pathways have been implicated in initiating and terminating hepatocyte proliferation; these have been comprehensively reviewed elsewhere ${ }^{1,21-24}$. Table 1 highlights some of the more recent findings that could have clinical implications ${ }^{25-43}$.

Table 1. Selected studies related to the regulation of hepatocyte proliferation.

\begin{tabular}{|c|c|}
\hline Reference & Observations \\
\hline $\begin{array}{l}\text { Buitrago-Molina } \\
\text { et al. }(2013)^{25}\end{array}$ & $\begin{array}{l}\text { Deletion of p } 21 \text { in mice with severe liver injury } \\
\text { leads to continued proliferation and facilitates HCC } \\
\text { development. }\end{array}$ \\
\hline $\begin{array}{l}\text { Nejak-Bowen } \\
\text { et al. }(2013)^{26}\end{array}$ & 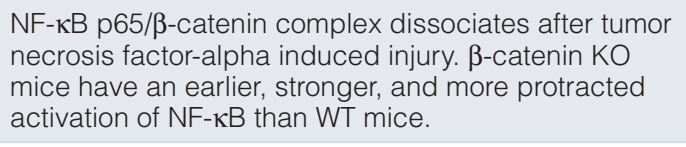 \\
\hline Xia et al. $(2013)^{27}$ & $\begin{array}{l}\text { HDAC1 and HDAC2 associate independently with } \\
\text { C/EBP } \beta \text { to upregulate Ki- } 67 \text { expression. }\end{array}$ \\
\hline Xu et al. $(2013)^{28}$ & $\begin{array}{l}\text { A long non-coding RNA (IncRNA) specifically } \\
\text { differentially expressed during liver regeneration } \\
\text { facilitates cyclin D1 expression by potentiating Wnt/ } \beta \text { - } \\
\text { catenin signaling through Axin1 suppression. }\end{array}$ \\
\hline $\begin{array}{l}\text { Yuan et al. } \\
(2013)^{29}\end{array}$ & $\begin{array}{l}\text { miR-221 promotes liver regeneration by targeting p27, } \\
\text { p57, and aryl hydrocarbon nuclear translocator (Arnt). }\end{array}$ \\
\hline $\begin{array}{l}\text { Amaya et al. } \\
(2014)^{30}\end{array}$ & $\begin{array}{l}\text { A subset of insulin receptors localize to the nucleus } \\
\text { upon insulin binding, generating InsP } \mathrm{P}_{3} \text {-dependent } \mathrm{Ca}^{2+} \\
\text { signals with pro-proliferative effects. }\end{array}$ \\
\hline $\begin{array}{l}\text { Fanti et al. } \\
(2014)^{31}\end{array}$ & $\begin{array}{l}\text { Thyroid hormone (T3) promotes } \beta \text {-catenin-TCF4 } \\
\text { reporter activity through protein kinase A-dependent } \\
\beta \text {-catenin activation (phosphorylation of Ser675). }\end{array}$ \\
\hline $\begin{array}{l}\text { Garcia-Rodriguez } \\
\text { et al. }(2014)^{32}\end{array}$ & $\begin{array}{l}\text { Over-expression of sirtuin1 (SIRT1), a class III histone } \\
\text { deacetylase, impairs regeneration after PH. }\end{array}$ \\
\hline $\begin{array}{l}\text { Kohler et al. } \\
(2014)^{33}\end{array}$ & $\begin{array}{l}\text { High levels of activated Nrf2 delay regeneration after } \\
\mathrm{PH} \text {, possibly allowing time for damage repair before } \\
\text { proliferation. }\end{array}$ \\
\hline $\begin{array}{l}\text { Rizzo et al. } \\
(2014)^{34}\end{array}$ & $\begin{array}{l}\text { Seventy-two out of about } 1400 \text { piRNAs show changes } \\
\text { in expression } 24 \text { to } 48 \text { hours after } \mathrm{PH} \text {, returning to } \\
\text { basal levels by } 168 \text { hours. }\end{array}$ \\
\hline $\begin{array}{l}\text { Starlinger et al. } \\
(2014)^{35}\end{array}$ & $\begin{array}{l}\text { Patients with low intraplatelet levels of serotonin }(5-\mathrm{HT}) \\
\text { have delayed hepatic regeneration. }\end{array}$ \\
\hline
\end{tabular}

\section{Comment}

p21 loss impairs regeneration in mice with chronic moderate injury with upregulation of sestrin-2. Sestrin-2 inhibits mTOR-mediated hepatocyte proliferation but also enhances the Nrf2-regulated oxidative stress response.

$\beta$-catenin inhibition in the context of cancer may have unintended consequences of promoting tumor cell survival.

Loss of HDAC1/2 impairs regeneration.

Pharmacological targeting of specific IncRNAs may aid regeneration.

Knockdown of miR-221 in HCC could reduce growth rate.

A number of potential targets have been identified for modulating hepatocyte proliferation.

T3 may be useful to induce regeneration in cases of hepatic insufficiency.

Aberrant SIRT1 over-expression could be targeted in metabolic liver disease involving dysregulated bile acid metabolism.

Caution is advised when using Nrf2-activating compounds for the prevention of liver damage.

The role of piRNAs in regeneration is unclear but is a new field of investigation.

Platelet levels of serotonin may predict clinical outcome after hepatic resection. 


\begin{tabular}{|c|c|c|}
\hline Reference & Observations & Comment \\
\hline Jin et al. $(2015)^{36}$ & $\begin{array}{l}\text { Expression of } \mathrm{C} / \mathrm{EBP} \alpha \text { opposes the pro-proliferative } \\
\text { effects of } \mathrm{C} / \mathrm{EBP} \beta \text {. Absence of active } \mathrm{C} / \mathrm{EBP} \alpha \text { leads to } \\
\text { hepatomegaly. }\end{array}$ & $\begin{array}{l}\text { Deregulation of the formation of complexes between C/EBP } \\
\text { proteins and chromatin remodeling proteins disrupts liver } \\
\text { homeostasis. }\end{array}$ \\
\hline $\begin{array}{l}\text { Nguyen et al. } \\
(2015)^{37}\end{array}$ & $\begin{array}{l}\text { YAP is a powerful stimulant of hepatic growth that } \\
\text { can be degraded via phosphorylation by the Hippo } \\
\text { signaling pathway. }\end{array}$ & $\begin{array}{l}\text { Reducing YAP protein levels or targeting YAP-TEAD } \\
\text { interactions may reduce hepatocyte/biliary proliferation. }\end{array}$ \\
\hline $\begin{array}{l}\text { Yang and Monga } \\
(2015)^{38}\end{array}$ & $\begin{array}{l}\text { Hepatocyte-secreted Wnt5a suppresses } \beta \text {-catenin } \\
\text { signaling in an autocrine manner through Frizzled-2, } \\
\text { terminating regeneration. }\end{array}$ & $\begin{array}{l}\text { Loss of termination signals such as Wnt5a may contribute } \\
\text { to dysregulated growth (for example, in tumors). }\end{array}$ \\
\hline $\begin{array}{l}\text { Zhang et al. } \\
(2015)^{39}\end{array}$ & $\begin{array}{l}\text { Wip1 suppresses liver regeneration through } \\
\text { dephosphorylation of mTOR. }\end{array}$ & $\begin{array}{l}\text { Wip1 inhibition can activate the } \mathrm{MTORC} 1 \text { pathway } \\
\text { to promote proliferation in situations in which liver } \\
\text { regeneration is critical. }\end{array}$ \\
\hline Kaji et al. $(2016)^{40}$ & $\begin{array}{l}\text { DNMT1 loss in hepatocytes causes global } \\
\text { hypomethylation, initiating senescence and a gradual } \\
\text { loss of regenerative capability. }\end{array}$ & $\begin{array}{l}\text { This triggers DNA damage and DNA damage response in } \\
\text { hepatocytes, leading to HPC expansion and differentiation } \\
\text { to hepatocytes. }\end{array}$ \\
\hline $\begin{array}{l}\text { Pauta et al. } \\
(2016)^{41}\end{array}$ & $\begin{array}{l}\text { The serine-threonine kinases Akt1 and Akt2 } \\
\text { phosphorylate and inactivate the transcription factor } \\
\text { FoxO1. }\end{array}$ & Double KO mice have impaired liver regeneration. \\
\hline Sun et al. $(2016)^{42}$ & $\begin{array}{l}\text { Loss of Arid } 1 \mathrm{~A} \text {, a SWI/SNF chromatin remodeling } \\
\text { complex component, enhances regeneration by } \\
\text { blocking chromatin access to transcription factors } \\
\text { that promote differentiation and inhibit proliferation (for } \\
\text { example, C/EBP } \alpha \text { ). }\end{array}$ & $\begin{array}{l}\text { Transient epigenetic reprogramming via Arid1A inhibition } \\
\text { may boost regeneration after severe injury. }\end{array}$ \\
\hline $\begin{array}{l}\text { Swiderska-Syn } \\
\text { et al. }(2016)^{43}\end{array}$ & $\begin{array}{l}\text { Disrupting Hedgehog signaling in myofibroblasts } \\
\text { inhibits regeneration after } \mathrm{PH} \text { and is associated with } \\
\text { a loss of paracrine signals that upregulate Yap1-and } \\
\text { Hedgehog-related transcription factors in hepatocytes. }\end{array}$ & $\begin{array}{l}\text { This demonstrates a critical role of paracrine stromal-to- } \\
\text { epithelial signaling for effective regeneration. }\end{array}$ \\
\hline
\end{tabular}

These are rodent studies unless stated otherwise. C/EBP, CCAAT-enhancer-binding protein; DNMT1, DNA methyltransferase 1; HCC, hepatocellular carcinoma; HDAC, histone deacetylase; HPC, hepatic progenitor cell; InsP3, inositol-1,4,5-trisphosphate; KO, knockout; mTOR, mammalian target of rapamycin; mTORC1, mammalian target of rapamycin complex 1; NF-кB, nuclear factor kappa B; Nrf2, nuclear factor erythroid 2-related factor 2; PH, partial hepatectomy; piRNA, P-element-induced wimpy testis (PIWI)-interacting RNA; SWI/SNF, SWItch/sucrose non-fermentable; TEAD, TEA domain family transcription factors; Wip1, Wildtype p53-induced phosphatase 1; Yap, Yes-associated protein.

The observations of the Nusse group of a largely diploid stem/ progenitor hepatocyte population in the immediate pericentral region ${ }^{14}$, if confirmed, raise a number of questions regarding regeneration after toxic injury and the role of this population in liver cancer histogenesis. Toxins such as $\mathrm{CCl}_{4}$ destroy the pericentral regions, yet the liver regenerates perfectly well from other hepatocytes, but can Axin2-positive hepatocytes be re-created after such injury and can their diploid status be re-established from polyploid hepatocytes? Cytokinesis without DNA synthesis in binucleated hepatocytes with diploid nuclei would be one way.

Perivenous diploid hepatocytes are also found in human liver ${ }^{3}$, so are there implications for liver pathology (for example, in the origins of hepatocellular carcinoma [HCC])? HCCs have similarities with Axin2-positive hepatocytes; many human HCCs are composed of diploid or near-diploid (aneuploid) hepatocytes ${ }^{4-46}$, and in childhood hepatoblastoma a small cell (diploid?) undifferentiated histology carries a poor prognosis ${ }^{47}$. Additionally, expression of nuclear $\beta$-catenin and GS can be found in $\mathrm{HCCs}^{48}$, and mutations in the $A P C, A X I N 1, A X I N 2$, and $C T N N B 1 / \beta$-catenin genes are common in human $\mathrm{HCCs}^{49,50}$.

\section{Periportal/portal stem cell niche(s)}

If normal homeostatic renewal is fed by pericentral hepatocytes, what happens after toxin-induced injury when pericentral cell death invariably features? HPCs derived from the canals of Hering can be mobilized when hepatocyte regeneration is compromised (see below), but another recent murine study suggests that chronic chemical damage induces clonal expansion of 'hybrid hepatocytes' (HybHPs) (Figure 2), so-called because they express the hepatic fate-determining transcription factor $\mathrm{HNF} 4 \alpha$, but also low levels of bile duct-enriched genes such as $\operatorname{Sox} 9$ and $O P N$, but no expression of the biliary cytokeratin CK19 ${ }^{51}$. These HybHPs comprised only $5 \%$ of all hepatocytes and exhibited a transcriptome unique from conventional hepatocytes and bile duct epithelia. In the mouse, these hepatocytes were found abutting the limiting plate, often in close association with the terminal branches of bile ducts. Lineage tracing found that HybHPs gave rise to only about $9 \%$ of hepatocytes 4 weeks after a single dose of $\mathrm{CCl}_{4}$ but contributed to two-thirds of hepatocytes after repeated $\mathrm{CCl}_{4}$ injections in Sox9-Cre ${ }^{E R T} ; R 26 R^{Y F P}$ mice within 12 weeks of tamoxifen treatment. The descendants of HybHPs extended from the portal tracts to the $\mathrm{CV}$, where they expressed GS, indicative of the new cells adopting the correct metabolic zonation. In the MUP-uPA (major urinary protein-urokinase-type plasminogen activator) mouse, where widespread DNA damage occurs because of endoplasmic stress caused by over-expression of uPA, HybHP progeny could reach the pericentral region within 5 to 6 weeks. Cholestatic injury induced many HybHPs to transdifferentiate to duct cells, strongly expressing Sox9, CK19, and OPN; so perhaps some ductular reactions 


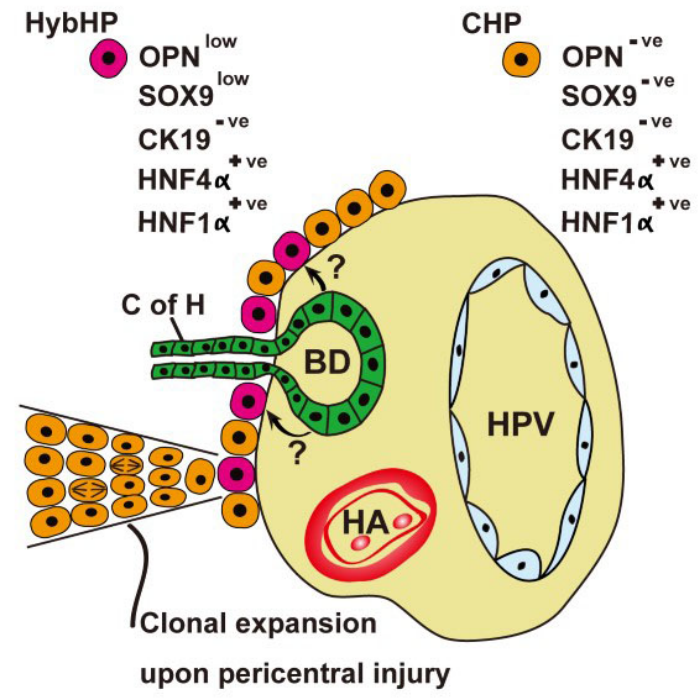

Figure 2. A periportal stem cell niche. A subpopulation of periportal hepatocytes (HybHPs) in intimate contact with the biliary epithelium can clonally expand upon liver injury, migrating towards the central veins. See section entitled 'periportal/portal stem cell niche(s)' and 51 for further details. Arrows indicate possible paracrine influences of biliary epithelium upon HybHPs. BD, bile duct; $\mathrm{CHP}$, conventional hepatocyte; $\mathrm{C}$ of $\mathrm{H}$, canal of Hering; $\mathrm{HA}$, hepatic artery; HPV, hepatic portal vein; HybHP, hybrid hepatocyte.

are derived from hepatocytes? Sox 9 and OPN are also expressed in some human periportal hepatocytes, suggesting that HybHPs are also found here. HybHPs were also compared with other hepatocytes for their ability to re-populate the fumarylacetoacetate hydrolase $\left(\mathrm{Fah}^{-/}\right)$null mouse, a model of hereditary tyrosinemia. HybHPs formed $\mathrm{Fah}^{+}$colonies 2.5-fold larger than those formed from conventional hepatocytes; moreover, mouse survival was vastly superior with HybHP transplantation compared with conventional hepatocyte transplantation. Finally, in three models of HCC formation, neither HPCs nor HybHPs contributed to tumor formation. This inability is probably due to the low expression of drug-metabolizing enzymes by these cells and, of course, is the reason why such cells are immune from the effects of chemicals that cause pericentral damage.

It is important to note that the rate of re-population by so-called HybHPs across the lobule (measured in weeks) was far too low to account for the restitution of liver structure (measured in days) after the likes of a single exposure to $\mathrm{CCl}_{4}$; thus, regenerative growth most likely involves all surviving hepatocytes. Moreover, if the pericentral niche is re-established after such an insult, is there a bidirectional flux of hepatocytes? Interestingly, hybrid/transitional/intermediate hepatocytes have also been noted by others in the immediate periportal area, but the relationship of these hepatocytes to HybHPs is unclear. For example, Isse et $a .^{52}$ reported on the presence of CK19-, HNF1 $\beta^{+}, \mathrm{HNF} 4 \alpha^{+}$hepatocytes in human liver, whereas the Reid group ${ }^{53}$ observed hepatoblasts expressing $\alpha$-fetoprotein, intercellular cell adhesion molecule-1 (ICAM-1), albumin, and membranous epithelial cell adhesion molecule (EpCAM) in the mouse liver. These hepatoblasts appeared to be tethered to the canals of Hering and, importantly, expanded in number during regenerative responses, just like HybHPs; so are these one and the same cells?

HPCs, named oval cells in rodents, give rise to the so-called ductular reaction that is observed in many forms of chronic liver injury. These cells undoubtedly have a biliary phenotype, but their cell of origin is in question. Additionally, there has been considerable debate as to the ability of oval cells/HPCs to generate meaningful numbers of hepatocytes. Ductular reactions probably arise from small intraportal bile ducts and from the canals of Hering, conduits that connect bile canaliculi to intraportal bile ducts $^{54}$. In both rats ${ }^{55}$ and mice ${ }^{56}$, retrograde ink injections via the extrahepatic bile duct have demonstrated continuity between the intraportal bile ducts and ductular reactions. On the other hand, it has been suggested that some ductular reactions arise from the transdifferentiation of hepatocytes; for example, mice fed diethoxycarbonyl-1,4-dihydrocollidine (DDC) generate ductular cells from albumin-positive hepatocytes ${ }^{57}$, seemingly reprogramming that is dependent on Notch signaling ${ }^{58}$, but it has been proposed that the ability of hepatocytes to reversibly transdifferentiate to ductular cells is a mechanism to escape injury and expand before redifferentiating to hepatocytes ${ }^{59}$. The latter study used the $\mathrm{Fah}^{-/-}$mouse that generates a severe form of tyrosinemia combined with DDC that causes bile duct destruction and cholestasis, circumstances so severe that some commentators ${ }^{60}$ have questioned the relevance of the findings to normal liver regeneration. However, there is evidence that some cholangiocarcinomas, originally considered to be derived from ductular epithelia, actually can have their origins in hepatocytes that have undergone ductular metaplasia ${ }^{61,62}$.

Doubts have been cast on the ability of HPCs to make a physiologically useful contribution to hepatocyte replacement in vivo ${ }^{63-65}$. Much of this skepticism seems to have arisen from the use of mechanistically different oval cell induction models. One classic model involves feeding rats 2-acetylaminofluorene (2-AAF), a compound that is metabolized by hepatocytes to form DNA adducts that render hepatocytes unable to proliferate in response to $2 / 3 \mathrm{PH}$. This model, in effect, mimics hepatocyte senescence, a seemingly key factor in inducing ductular reactions when chronic liver injury occurs. With this model, a number of studies suggest that oval cells can undergo hepatocytic differentiation ${ }^{55,66-68}$; moreover, studies of human liver cirrhosis indicate that HPCs also give rise to regenerative hepatocyte nodules ${ }^{69,70}$. A lack of any significant contribution by ductular cells to hepatocytes in several injury models could be due to the fact that a complete hepatocyte-senescence-like state is not achieved; Yanger et al. ${ }^{64}$ used DDC, which targets the biliary epithelium, and a choline-deficient, ethionine-supplemented (CDE) diet that induces a fatty liver; the latter model was also used by Schaub et al. ${ }^{65}$.

A further study has now shown how crucial the blockade of hepatocyte regeneration is to HPC activation and differentiation, with complete re-population of the injured liver by nascent hepatocytes under the CDE diet regime ${ }^{71}$ ! Lu et al. ${ }^{71}$ inactivated the $M d m 2$ gene in hepatocytes, promoting a rise in $\mathrm{p} 53$ and increased expression of $\mathrm{p} 21^{\text {Cipl }}$ and Bax. The resultant hepatocyte senescence and apoptosis led to the almost complete re-population of the liver by HPCderived hepatocytes (Figure 3). A detailed account of the molecular regulation of the ductular reaction is beyond the scope of this review, 


\section{(a)}
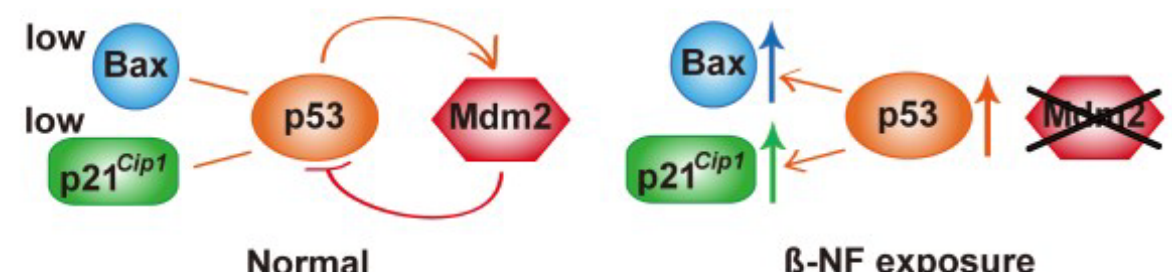

Normal

\section{B-NF exposure}

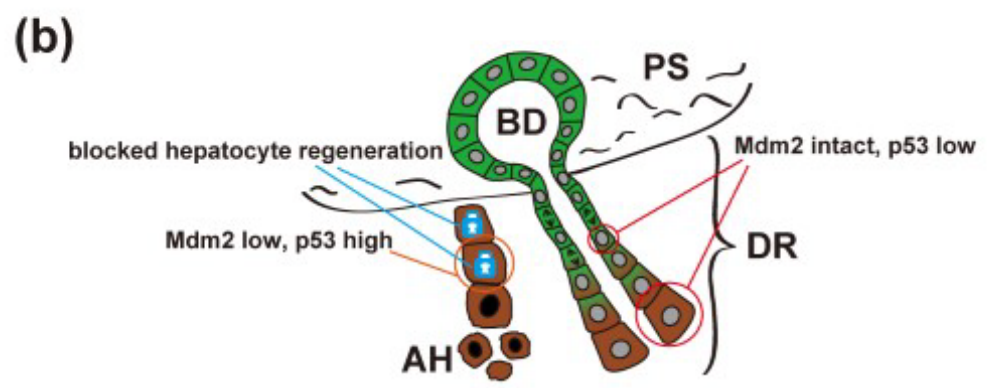

Figure 3. A model for major hepatic progenitor cell activation and hepatocytic differentiation. (a) Molecular mechanism: $\beta$-NF injection leads to hepatocyte-specific deletion of $m d m 2$, in turn reducing proteasomal destruction of p53 and upregulation of p53 targets p21 and Bax. (b) Cartoon of histological consequences: hepatocytes (brown cytoplasm) undergo cell cycle arrest and apoptosis as a consequence of upregulation of p21 and Bax, respectively. The ductular (green cytoplasm) reaction (DR) is activated, leading to columns of proliferating cells migrating into the parenchyma and eventually differentiating to hepatocytes. See section entitled 'periportal/portal stem cell niche(s)' and 71 for further details. $\beta$-NF; $\beta$-Naphthoflavone; $\mathrm{AH}$, apoptotic hepatocyte; $\mathrm{BD}$, bile duct; PS, portal space.

but important molecules include the cytokine tumor necrosis factorlike weak inducer of apoptosis (TWEAK) $)^{72}$, neural cell adhesion molecule $(\mathrm{NCAM})^{73}$, polycomb-group proteins ${ }^{74}$, connective tissue growth factor $(\mathrm{CTGF})^{75}$, Notch ligands ${ }^{76}$, and integrin $\alpha v \beta 6$ dependent transforming growth factor-beta 1 (TGF $\beta 1$ ) activation ${ }^{77}$.

This review has illustrated some recent observations regarding liver regeneration. We suggest that the functional significance of HPCs is very much dependent on the liver injury model used and that hepatocyte senescence in the face of injury is a major driver for HPC expansion and differentiation. Additionally, we have highlighted studies identifying new stem/progenitor hepatocytes at opposite ends of the PV-CV axis: at the portal rim, clonogenic HybHPs are activated only in response to damage, whereas pericentral hepatocytes are proposed to be responsible for normal turnover, moving in the opposite direction. A recent article has failed to confirm the presence of pericentral stem/progenitor cells ${ }^{19}$. The kinetics of clonogenic expansion from HybHPs is relatively slow, but since midzonal/centrilobular necrosis induced by the likes of a single injection of $\mathrm{CCl}_{4}$ can be repaired within a few days, hepatocyte self-duplication from other surviving hepatocytes must occur, undoubtedly as the dominant mechanism. On the other hand, HybHPs may have superior potential over conventional hepatocytes as a cell therapy. What is certain is that recent studies have revived the debate on the nature of liver regeneration on two counts: firstly, whether the liver conforms to a stem cell and lineage system and, secondly, whether hepatocytes do migrate (stream) and, if so, which way? Or do they migrate both ways?

\section{Competing interests}

The authors declare that they have no competing interests.

\section{Grant information}

The author(s) declared that no grants were involved in supporting this work. 
1. Alison MR, Islam S, Lim S: Stem cells in liver regeneration, fibrosis and cancer: the good, the bad and the ugly. J Pathol. 2009; 217(2): 282-98. PubMed Abstract | Publisher Full Text

2. Zajicek G, Oren R, Weinreb M Jr: The streaming liver. Liver. 1985; 5(6): 293-300. PubMed Abstract | Publisher Full Text

3. Turner R, Lozoya O, Wang $\mathrm{Y}$, et al:: Human hepatic stem cell and maturational liver lineage biology. Hepatology. 2011; 53(3): 1035-45.

PubMed Abstract | Publisher Full Text | Free Full Text

4. F Fellous TG, Islam S, Tadrous PJ, et al:: Locating the stem cell niche and tracing hepatocyte lineages in human liver. Hepatology. 2009; 49(5): 1655-63. PubMed Abstract | Publisher Full Text | F1000 Recommendation

5. Walther V, Alison MR: Cell lineage tracing in human epithelial tissues using mitochondrial DNA mutations as clonal markers. Wiley Interdiscip Rev Dev Biol. 2016; 5(1): 103-17.

PubMed Abstract | Publisher Full Text

6. F Kuwahara R, Kofman AV, Landis CS, et al:: The hepatic stem cell niche: identification by label-retaining cell assay. Hepatology. 2008; 47(6): 1994-2002. PubMed Abstract | Publisher Full Text | Free Full Text | F1000 Recommendation

7. $\mathrm{F}$ Furuyama $\mathrm{K}$, Kawaguchi $\mathrm{Y}$, Akiyama $\mathrm{H}$, et al.: Continuous cell supply from a Sox9-expressing progenitor zone in adult liver, exocrine pancreas and intestine. Nat Genet. 2011; 43(1): 34-41.

PubMed Abstract | Publisher Full Text | F1000 Recommendation

8. Tarlow BD, Finegold MJ, Grompe M: Clonal tracing of Sox $9^{+}$liver progenitors in mouse oval cell injury. Hepatology. 2014; 60(1): 278-89. PubMed Abstract | Publisher Full Text | Free Full Text

9. $\quad \mathrm{F}$ Carpentier R, Suñer $\mathrm{RE}$, van Hul $\mathrm{N}$, et al:: Embryonic ductal plate cells give rise to cholangiocytes, periportal hepatocytes, and adult liver progenitor cells. Gastroenterology. 2011; 141(4): 1432-8, 1438.e1-4.

PubMed Abstract | Publisher Full Text | Free Full Text | F1000 Recommendation

10. $\mathrm{F}$ Malato $\mathrm{Y}, \mathrm{Naqvi} \mathrm{S}$, Schürmann $\mathrm{N}$, et al:: Fate tracing of mature hepatocytes in mouse liver homeostasis and regeneration. J Clin Invest. 2011; 121(12): 4850-60.

PubMed Abstract | Publisher Full Text | Free Full Text | F1000 Recommendation

11. Bralet MP, Branchereau S, Brechot $C$, et al: Cell lineage study in the liver using retroviral mediated gene transfer. Evidence against the streaming of hepatocytes in normal liver. Am J Pathol. 1994; 144(5): 896-905. PubMed Abstract | Free Full Text

12. Ponder KP: Analysis of liver development, regeneration, and carcinogenesis by genetic marking studies. FASEB J. 1996; 10(7): 673-82. PubMed Abstract

13. Kopp JL, Grompe M, Sander M: Stem cells versus plasticity in liver and pancreas regeneration. Nat Cell Biol. 2016; 18(3): 238-45. PubMed Abstract | Publisher Full Text

14. F Wang B, Zhao L, Fish M, et al:: Self-renewing diploid Axin2+ cells fuel homeostatic renewal of the liver. Nature. 2015; 524(7564): 180-5. PubMed Abstract | Publisher Full Text | Free Full Text | F1000 Recommendation

15. Jho EH, Zhang T, Domon $\mathrm{C}$, et al:: Wnt/beta-catenin/Tcf signaling induces the transcription of Axin2, a negative regulator of the signaling pathway. $\mathrm{Mol} \mathrm{Cell}$ Biol. 2002; 22(4): 1172-83.

PubMed Abstract | Publisher Full Text | Free Full Text

16. Kuo FC, Darnell JE Jr: Evidence that interaction of hepatocytes with the collecting (hepatic) veins triggers position-specific transcription of the glutamine synthetase and ornithine aminotransferase genes in the mouse liver. Mol Cell Biol. 1991; 11(12): 6050-8. PubMed Abstract | Publisher Full Text | Free Full Text

17. F Benhamouche S, Decaens T, Godard C, et al:: Apc tumor suppressor gene is the "zonation-keeper" of mouse liver. Dev Cell. 2006; 10(6): 759-70. PubMed Abstract | Publisher Full Text | F1000 Recommendation

18. Monga SP: $\beta$-Catenin Signaling and Roles in Liver Homeostasis, Injury, and Tumorigenesis. Gastroenterology. 2015; 148(7): 1294-310. PubMed Abstract | Publisher Full Text | Free Full Text

19. F Planas-Paz L, Orsini V, Boulter L, et al:: The RSPO-LGR4/5-ZNRF3/RNF43 module controls liver zonation and size. Nat Cell Biol. 2016; 18(5): 467-79. PubMed Abstract | Publisher Full Text | F1000 Recommendation

20. Birchmeier W: Orchestrating Wnt signalling for metabolic liver zonation. Nat Cell Biol. 2016; 18(5): 463-5.

PubMed Abstract | Publisher Full Text

21. Michalopoulos GK: Liver regeneration. J Cell Physiol. 2007; 213(2): 286-300 PubMed Abstract | Publisher Full Text | Free Full Text

22. Michalopoulos GK, DeFrances MC: Liver regeneration. Science. 1997; 276(5309): 60-6.

PubMed Abstract | Publisher Full Text

23. Michalopoulos GK: Principles of liver regeneration and growth homeostasis. Compr Physiol. 2013; 3(1): 485-513. PubMed Abstract | Publisher Full Text

24. F Michalopoulos GK: Advances in liver regeneration. Expert Rev Gastroenterol
Hepatol. 2014; 8(8): 897-907.

PubMed Abstract | Publisher Full Text | F1000 Recommendation

25. Buitrago-Molina LE, Marhenke S, Longerich T, et al.: The degree of liver injury determines the role of p21 in liver regeneration and hepatocarcinogenesis in mice. Hepatology. 2013; 58(3): 1143-52. PubMed Abstract | Publisher Full Text

26. Nejak-Bowen K, Kikuchi A, Monga SP: Beta-catenin-NF-кB interactions in murine hepatocytes: a complex to die for. Hepatology. 2013; 57(2): 763-74. PubMed Abstract | Publisher Full Text | Free Full Text

27. Xia J, Zhou Y, Ji H, et al.: Loss of histone deacetylases 1 and $\mathbf{2}$ in hepatocytes impairs murine liver regeneration through Ki67 depletion. Hepatology. 2013; 58(6): 2089-98.

PubMed Abstract | Publisher Full Text

28. Xu D, Yang F, Yuan JH, et al.: Long noncoding RNAs associated with liver regeneration 1 accelerates hepatocyte proliferation during liver regeneration by activating Wnt/ $\beta$-catenin signaling. Hepatology. 2013; 58(2): 739-51. PubMed Abstract | Publisher Full Text

29. Yuan Q, Loya K, Rani B, et al:: MicroRNA-221 overexpression accelerates hepatocyte proliferation during liver regeneration. Hepatology. 2013; 57(1): 299-310.

PubMed Abstract | Publisher Full Text

30. F Amaya MJ, Oliveira AG, Guimarães ES, et al:: The insulin receptor translocates to the nucleus to regulate cell proliferation in liver. Hepatology. 2014; 59(1): 274-83.

PubMed Abstract | Publisher Full Text | Free Full Text | F1000 Recommendation

31. F Fanti M, Singh S, Ledda-Columbano GM, et al:: Tri-iodothyronine induces hepatocyte proliferation by protein kinase A-dependent $\beta$-catenin activation in rodents. Hepatology. 2014; 59(6): 2309-20.

PubMed Abstract | Publisher Full Text | Free Full Text | F1000 Recommendation

32. F García-Rodríguez JL, Barbier-Torres L, Fernández-Álvarez S, et al:: SIRT1 controls liver regeneration by regulating bile acid metabolism through farnesoid $\mathrm{X}$ receptor and mammalian target of rapamycin signaling. Hepatology. 2014; 59(5): 1972-83.

PubMed Abstract | Publisher Full Text | Free Full Text | F1000 Recommendation

33. F Köhler UA, Kurinna S, Schwitter D, et al:: Activated Nrf2 impairs liver regeneration in mice by activation of genes involved in cell-cycle control and apoptosis. Hepatology. 2014; 60(2): 670-8.

PubMed Abstract | Publisher Full Text | F1000 Recommendation

34. Rizzo F, Hashim A, Marchese G, et al.: Timed regulation of P-element-induced wimpy testis-interacting RNA expression during rat liver regeneration. Hepatology. 2014; 60(3): 798-806

PubMed Abstract | Publisher Full Text

35. F Starlinger $\mathrm{P}$, Assinger A, Haegele $\mathrm{S}$, et al.: Evidence for serotonin as a relevant inducer of liver regeneration after liver resection in humans. Hepatology. 2014; 60(1): 257-66.

PubMed Abstract | Publisher Full Text | F1000 Recommendation

36. Jin J, Hong $\mathrm{IH}$, Lewis $\mathrm{K}$, et al:: Cooperation of C/EBP family proteins and chromatin remodeling proteins is essential for termination of liver regeneration. Hepatology. 2015; 61(1): 315-25. PubMed Abstract | Publisher Full Text | Free Full Text

37. F Nguyen $\mathrm{Q}$, Anders RA, Alpini G, et al:: Yes-associated protein in the liver: Regulation of hepatic development, repair, cell fate determination and tumorigenesis. Dig Liver Dis. 2015; 47(10): 826-35. PublMed Abstract | Publisher Full Text | F1000 Recommendation

38. Yang J, Cusimano A, Monga JK, et al.: WNT5A inhibits hepatocyte proliferation and concludes $\beta$-catenin signaling in liver regeneration. Am J Pathol. 2015; 185(8): 2194-205.

PubMed Abstract | Publisher Full Text | Free Full Text

39. $F$ Zhang L, Liu L, He Z, et al.: Inhibition of wild-type p53-induced phosphatase 1 promotes liver regeneration in mice by direct activation of mammalian target of rapamycin. Hepatology. 2015; 61(6): 2030-41.

PubMed Abstract | Publisher Full Text | F1000 Recommendation

40. Kaji K, Factor VM, Andersen JB, et al.: DNMT1 is a Required Genomic Regulator for Murine Liver Histogenesis and Regeneration. Hepatology. 2016; 64(2): 582-598.

PubMed Abstract | Publisher Full Text

41. Pauta M, Rotllan N, Fernández-Hernando A, et al:: Akt-mediated foxo1 inhibition is required for liver regeneration. Hepatology. 2016; 63(5): 1660-74. PubMed Abstract | Publisher Full Text

42. F Sun X, Chuang JC, Kanchwala M, et al:: Suppression of the SWI/SNF Component Arid1a Promotes Mammalian Regeneration. Cell Stem Cell. 2016; 18(4): 456-66.

PubMed Abstract | Publisher Full Text | Free Full Text | F1000 Recommendation

43. F Swiderska-Syn M, Xie G, Michelotti GA, et al:: Hedgehog regulates yesassociated protein 1 in regenerating mouse liver. Hepatology. 2016; 64(1): 232-44.

PubMed Abstract | Publisher Full Text | Free Full Text | F1000 Recommendation 
44. Anti M, Marra G, Rapaccini GL, et al.: DNA ploidy pattern in human chronic liver diseases and hepatic nodular lesions. Flow cytometric analysis on echoguided needle liver biopsy. Cancer. 1994; 73(2): 281-8.

PubMed Abstract | Publisher Full Text

45. Attallah AM, Tabll AA, Salem SF, et al:: DNA ploidy of liver biopsies from patients with liver cirrhosis and hepatocellular carcinoma: a flow cytometric analysis. Cancer Lett. 1999; 142(1): 65-9. PubMed Abstract | Publisher Full Text

46. $\mathrm{Ng} \mathrm{IO}$, Lai EC, Ho JC, et al:: Flow cytometric analysis of DNA ploidy in hepatocellular carcinoma. Am J Clin Pathol. 1994; 102(1): 80-6. PubMed Abstract | Publisher Full Text

47. Haas JE, Feusner JH, Finegold MJ: Small cell undifferentiated histology in hepatoblastoma may be unfavorable. Cancer. 2001; 92(12): 3130-4. PubMed Abstract | Publisher Full Text

48. $\mathrm{F}$ Tward $\mathrm{AD}$, Jones $\mathrm{KD}$, Yant $\mathrm{S}$, et al.: Distinct pathways of genomic progression to benign and malignant tumors of the liver. Proc Natl Acad Sci U S A. 2007; 104(37): 14771-6.

PubMed Abstract | Publisher Full Text | Free Full Text | F1000 Recommendation

49. Laurent-Puig P, Zucman-Rossi J: Genetics of hepatocellular tumors. Oncogene. 2006; 25(27): 3778-86.

PubMed Abstract | Publisher Full Text

50. Taniguchi K, Roberts LR, Aderca IN, et al:: Mutational spectrum of beta-catenin, AXIN1, and AXIN2 in hepatocellular carcinomas and hepatoblastomas. Oncogene. 2002; 21(31): 4863-71. PubMed Abstract | Publisher Full Tex

51. F Font-Burgada J, Shalapour S, Ramaswamy S, et al.: Hybrid Periportal Hepatocytes Regenerate the Injured Liver without Giving Rise to Cancer. Cell. 2015; 162(4): 766-79.

PubMed Abstract | Publisher Full Text | Free Full Text | F1000 Recommendation

52. Isse K, Lesniak A, Grama K, et al:: Preexisting epithelial diversity in norma human livers: a tissue-tethered cytometric analysis in portal/periportal epithelial cells. Hepatology. 2013; 57(4): 1632-43. PubMed Abstract | Publisher Full Text | Free Full Text

53. Zhang L, Theise $\mathrm{N}$, Chua $\mathrm{M}$, et al:: The stem cell niche of human livers: symmetry between development and regeneration. Hepatology. 2008; 48(5): 1598-607.

PubMed Abstract | Publisher Full Text

54. Theise ND, Saxena R, Portmann BC, et al:: The canals of Hering and hepatic stem cells in humans. Hepatology. 1999; 30(6): 1425-33. PubMed Abstract | Publisher Full Text

55. Sarraf C, Lalani EN, Golding M, et al.: Cell behavior in the acetylaminofluorenetreated regenerating rat liver. Light and electron microscopic observations. Am J Pathol. 1994; 145(5): 1114-26. PubMed Abstract | Free Full Text

56. F Kaneko K, Kamimoto K, Miyajima A, et al:: Adaptive remodeling of the biliary architecture underlies liver homeostasis. Hepatology. 2015; 61(6): 2056-66. PubMed Abstract | Publisher Full Text | F1000 Recommendation

57. F Sekiya S, Suzuki A: Hepatocytes, rather than cholangiocytes, can be the major source of primitive ductules in the chronically injured mouse liver. $A m \mathrm{~J}$ Pathol. 2014; 184(5): 1468-78. PubMed Abstract | Publisher Full Text | F1000 Recommendation

58. $\mathrm{F}$ Yanger $\mathrm{K}$, Zong $\mathrm{Y}$, Maggs $\mathrm{LR}$, et al:: Robust cellular reprogramming occurs spontaneously during liver regeneration. Genes Dev. 2013; 27(7): 719-24. PubMed Abstract | Publisher Full Text | Free Full Text | F1000 Recommendation

59. F Tarlow BD, Pelz C, Naugler WE, et al:: Bipotential adult liver progenitors are derived from chronically injured mature hepatocytes. Cell Stem Cell. 2014; 15(5): 605-18.

PubMed Abstract | Publisher Full Text | Free Full Text | F1000 Recommendation

60. Reid LM: Paradoxes in studies of liver regeneration: Relevance of the parable of the blind men and the elephant. Hepatology. 2015; 62(2): 330-3. PubMed Abstract | Publisher Full Text

61. F Sekiya S, Suzuki A: Intrahepatic cholangiocarcinoma can arise from
Notch-mediated conversion of hepatocytes. J Clin Invest. 2012; 122(11): 3914-8. PubMed Abstract | Publisher Full Text | Free Full Text | F1000 Recommendation

62. $\mathrm{F}$ Fan B, Malato $\mathrm{Y}$, Calvisi DF, et al:: Cholangiocarcinomas can originate from hepatocytes in mice. J Clin Invest. 2012; 122(8): 2911-5.

PubMed Abstract | Publisher Full Text | Free Full Text | F1000 Recommendation

63. Grompe M: Liver stem cells, where art thou? Cell Stem Cell. 2014; 15(3): 257-8. PubMed Abstract | Publisher Full Text

64. $\mathrm{F}$ Yanger $\mathrm{K}$, Knigin D, Zong $\mathrm{Y}$, et al:: Adult hepatocytes are generated by self-duplication rather than stem cell differentiation. Cell Stem Cell. 2014; 15(3): 340-9.

PubMed Abstract | Publisher Full Text | Free Full Text | F1000 Recommendation

65. F Schaub JR, Malato Y, Gormond C, et al.: Evidence against a stem cell origin of new hepatocytes in a common mouse model of chronic liver injury. Cell Rep. 2014; 8(4): 933-9.

PubMed Abstract | Publisher Full Text | Free Full Text | F1000 Recommendation

66. Evarts RP, Nagy P, Marsden E, et al:: A precursor-product relationship exists between oval cells and hepatocytes in rat liver. Carcinogenesis. 1987; 8(11): 1737-40.

PubMed Abstract | Publisher Full Text

67. Golding M, Sarraf CE, Lalani EN, et al.: Oval cell differentiation into hepatocytes in the acetylaminofluorene-treated regenerating rat liver. Hepatology. 1995; 22(4 Pt 1): 1243-53.

PubMed Abstract | Publisher Full Text

68. Alison MR, Golding M, Sarraf CE, et al.: Liver damage in the rat induces hepatocyte stem cells from biliary epithelial cells. Gastroenterology. 1996; 110(4): 1182-90.

PubMed Abstract | Publisher Full Text

69. Lin WR, Lim SN, McDonald SA, et al:: The histogenesis of regenerative nodules in human liver cirrhosis. Hepatology. 2010; 51(3): 1017-26. PubMed Abstract | Publisher Full Text

70. F Stueck AE, Wanless IR: Hepatocyte buds derived from progenitor cells repopulate regions of parenchymal extinction in human cirrhosis. Hepatology. 2015; 61(5): 1696-707.

PubMed Abstract | Publisher Full Text | F1000 Recommendation

71. F Lu WY, Bird TG, Boulter L, et al:: Hepatic progenitor cells of biliary origin with liver repopulation capacity. Nat Cell Biol. 2015; 17(8): 971-83. PubMed Abstract | Publisher Full Text | Free Full Text | F1000 Recommendation

72. $\mathrm{F}$ Bird TG, Lu WY, Boulter L, et al.: Bone marrow injection stimulates hepatic ductular reactions in the absence of injury via macrophage-mediated TWEAK signaling. Proc Natl Acad Sci U S A. 2013; 110(16): 6542-7.

PubMed Abstract | Publisher Full Text | Free Full Text | F1000 Recommendation

73. F Tsuchiya A, Lu WY, Weinhold B, et al.: Polysialic acid/neural cell adhesion molecule modulates the formation of ductular reactions in liver injury. Hepatology. 2014; 60(5): 1727-40.

PubMed Abstract | Publisher Full Text | F1000 Recommendation

74. Koike H, Ueno $\mathrm{Y}$, Naito $\mathrm{T}$, et al:: Ring1B promotes hepatic stem/progenitor cell expansion through simultaneous suppression of Cdkn1a and Cdkn2a in mice. Hepatology. 2014; 60(1): 323-33.

PubMed Abstract | Publisher Full Text

75. F Pi L, Robinson PM, Jorgensen M, et al:: Connective tissue growth factor and integrin $\alpha \mathrm{V} \beta 6$ : a new pair of regulators critical for ductular reaction and biliary fibrosis in mice. Hepatology. 2015; 61(2): 678-91.

PubMed Abstract | Publisher Full Text | Free Full Text | F1000 Recommendation

76. F Kaylan KB, Ermilova V, Yada RC, et al.: Combinatorial microenvironmenta regulation of liver progenitor differentiation by Notch ligands, TGF $\beta$, and extracellular matrix. Sci Rep. 2016; 6: 23490.

PubMed Abstract | Publisher Full Text | Free Full Text | F1000 Recommendation

77. F Peng ZW, Ikenaga N, Liu SB, et al.: Integrin $\alpha v \beta 6$ critically regulates hepatic progenitor cell function and promotes ductular reaction, fibrosis, and tumorigenesis. Hepatology. 2016; 63(1): 217-32.

PubMed Abstract | Publisher Full Text | F1000 Recommendation 


\section{Open Peer Review}

\section{Current Peer Review Status:}

\section{Editorial Note on the Review Process}

Faculty Reviews are review articles written by the prestigious Members of Faculty Opinions. The articles are commissioned and peer reviewed before publication to ensure that the final, published version is comprehensive and accessible. The reviewers who approved the final version are listed with their names and affiliations.

\section{The reviewers who approved this article are:}

\section{Version 1}

\section{Anna Mae Diehl}

Division of Gastroenterology, Department of Medicine, Duke University Medical Center, Durham, NC, USA

Competing Interests: No competing interests were disclosed.

\section{Lola Reid}

Department of Cell Biology and Physiology, Program in Molecular Biology and Biotechnology, University of North Carolina School of Medicine, Chapel Hill, NC, USA

Competing Interests: No competing interests were disclosed.

\section{George Michalopoulos}

Department of Pathology, University of Pittsburgh School of Medicine, Pittsburgh, PA, USA

Competing Interests: No competing interests were disclosed.

The benefits of publishing with F1000Research:

- Your article is published within days, with no editorial bias

- You can publish traditional articles, null/negative results, case reports, data notes and more

- The peer review process is transparent and collaborative

- Your article is indexed in PubMed after passing peer review

- Dedicated customer support at every stage

For pre-submission enquiries, contact research@f1000.com 